- Social Justice Forum

\title{
Vocational Research for the Liberation of Battered Women
}

\author{
Krista M. Chronister \\ University of Oregon \\ Kara Brita Wettersten \\ University of North Dakota \\ Chris Brown \\ University of Missouri, Kansas City
}

\begin{abstract}
Domestic violence interferes with women's exploration of career interests, pursuit of career goals, and attainment of economic independence. Vocational research may contribute significantly to preventive-intervention efforts against domestic violence and to the liberation of battered women by increasing their economic stability and strengthening their support network. In this article, the authors' aim is to inspire vocational research with battered women. We use Prilleltensky's emancipatory communitarian approach to outline a vocational research agenda with battered women and to describe research practices that facilitate collaboration among researchers and community stakeholders and that increase battered women's self-determination and contribution to their communities. We discuss general research and specific vocational research practices to assist researchers with building research partnerships, recruiting and retaining partici-

pants, and disseminating vocational research results to effect social change.
\end{abstract}

Domestic violence is defined as a pattern of coercive control consisting of physical, verbal, or sexual acts against former or current intimate partners (Flitcraft, Hadley, Hendricks-Matthews, McLeer, \& Warshaw, 1992). The U.S. Department of Justice $(2000,2001)$ reported that $64 \%$ to $85 \%$ of domestic violence victims are women, and it is estimated that more than three women are murdered daily in the United States by male partners. Domestic assaults may occur as physical (e.g., punching), sexual (e.g., physically forcing sex), psychological (e.g., humiliating in private or public), and/or economic abuse (e.g., sabotaging attempts to work or to go to school).

An estimated 13,000 episodes of intimate-partner violence toward women occur at work (Corporate Alliance to End Partner Violence [CAEPV], 2002; U.S. Department of Labor, 1996). In a national survey, $40 \%$ of battered women reported that domestic abuse caused them to be late for work more than three times in the previous month, $34 \%$ reported missing whole days from work, $23 \%$ reported difficulties advancing in their careers, and 20\% reported difficulties keeping their jobs (Retzlaff, 1999). These sta-

THE COUNSELING PSYCHOLOGIST, Vol. 32 No. 6, November $2004900-922$

DOI: $10.1177 / 0011000004269300$

(C) 2004 by the Society of Counseling Psychology

900 
tistics show that battered women's career development is severely restricted because of difficulties keeping jobs, performing occupational tasks, and earning promotions. In a qualitative study of the impact of domestic violence on women's work, Wettersten et al. (in press) found that women reported receiving mixed messages about their work (e.g., partner approved of work and then threatened her if she did not quit her job) and experiencing harassment at work, difficulty concentrating at work, absenteeism, loss of work opportunities, lowered self-concept, work as an escape from the abusive relationship, and economic control and restriction.

Domestic violence permeates all social, religious, and ethnic groups. It is widely argued that domestic abuse also extends equally across socioeconomic groups (Browne, Salomon, \& Bassuk, 1999; Plichta, 1996; Tjaden \& Thoennes, 2000), but there is a growing body of literature that suggests otherwise. The U.S. Department of Justice (1998) found that women living in poor households were four times more likely to experience a violent intimatepartner assault (including rape, sexual assault, physical assault, and robbery) than women not living in poor households. Similarly, Browne et al. (1999) argued that a higher prevalence of domestic violence or more extreme and violent abuse is apparent in literature related to women and welfare. The impact of domestic violence on women from all cultural and socioeconomic backgrounds is broad, and vocational research that improves women's educational and career achievements as well as economic attainments is warranted. There has been little research, however, regarding the potential of vocational research to contribute to women's career and economic development, domestic-violence preventive-intervention efforts, and liberation (Bowen, 1982; C. Brown, 2001; C. Brown, Reedy, Fountain, Johnson, \& Dichiser, 2000; Gianakos, 1999; Ibrahim \& Herr, 1987).

The purpose of this article is to stimulate and inspire research on the vocational experiences and needs of battered women - research that will advance the contributions of vocational research to the liberation of battered women. Toward these aims, we first define liberation. Second, we outline Isaac Prilleltensky's emancipatory communitarian framework for psychological practice (Prilleltensky 1997; Prilleltensky \& Nelson, 2002). Third, we use an emancipatory communitarian framework to delineate a vocational research agenda with battered women and to identify research practices that support the inclusion of women's voices in research processes (Prilleltensky, 1997). Given the dearth of vocational research with battered women, the vocational research agenda and practices that we describe are informed by a broad literature base (counseling psychology, liberation psychology, vocational psychology, social work, and violence prevention) and are a synthesis of our applied experiences conducting vocational research with battered women. 


\section{DEFINITIONS}

\section{Prevention}

To describe the potential contribution of vocational research to domesticviolence preventive-intervention efforts, we use Romano and Hage's (2000) definition of a prevention effort. They define it as having one or more of the following five dimensions: (a) prevents a problem behavior from ever occurring; (b) delays the onset of a problem behavior; (c) reduces the impact of an existing problem behavior; (d) strengthens knowledge, attitudes, and behaviors that promote emotional and physical well-being; and (e) supports institutional, community, and government policies that promote physical and emotional well-being (Romano \& Hage, 2000). Vocational research may be an important entrée for many women to receive other preventive-intervention services. That is, services associated with vocational research (e.g., assessment, career counseling) have fewer stigmas than more traditional therapy and counseling services. Consequently, women who may not feel comfortable seeking individual or group therapy may instead turn to careercounseling services.

We believe that vocational research can help reduce the devastating impact of domestic violence on women's health because research has shown that women who have access to financial resources (e.g., consistent employment, state emergency grant money, financial assistance from family and friends) are more likely to seek help (Sullivan \& Bybee, 1999). In addition, vocational research may contribute to domestic-violence prevention efforts by strengthening women's vocational skills and support networks, which promote greater life satisfaction and well-being, and by informing policy that supports the integration of vocational research and practice as part of routine social services for battered women. Moreover, we use this prevention definition because it includes preventive-intervention efforts within larger social systems and acknowledges researchers' role as agents of social change.

\section{Liberation}

To fully understand liberation, we begin with concientización, or the process of developing critical consciousness. Concientización was first defined by Brazilian educator Paulo Freire (1970). Ignacio Martín-Baró (1994) applied it to the practice of psychotherapy and described it as

learning to say the word of one's own existence,.. and to pronounce that personal and collective word, people must take hold of their fate, . . a move that demands overcoming false consciousness and achieving a critical understanding of themselves as well as of their world and where they stand in it. (p. 40) 
Concientización supposes that persons change in the process of changing their relations with their environment and with other people (Martín-Baró, 1994). This change process is known as liberation - the action counterpart of the psychological changes associated with critical consciousness.

Liberation of battered women is the process by which they surmount their situations of oppression by first critically recognizing its causes so that through transforming action, they-and their communities-can create a new situation (Freire, 1970). A woman survivor may begin to increase her critical consciousness through dialogue with supportive community members, including counselors, friends, or family members. Dialogue with others facilitates the woman survivor's understanding of the effects of abuse on her beliefs about herself, her abilities, and her health and goal attainments. She begins to see more clearly how her partner's abuse has hindered her ability to concentrate and perform well at work or to study for school exams. As a result of increased critical consciousness, the woman survivor is less likely to blame herself for her poor school or work performance, to believe that she is incompetent, and to feel helpless in directing her future. New knowledge and potential also comes with increased critical consciousness. The woman survivor may begin to take action against her oppressive situation and to transform her life as she becomes more critically aware of her skills, resources, and ability to make autonomous choices to determine her future (ComasDíaz, 1994; Martín-Baró, 1994). The woman survivor redefines herself and her reality and makes choices to change her abusive situation.

Liberation also must include the increased critical consciousness of women's communities. It is the responsibility of community members, including counseling psychologists, health care and social service providers, educators, and government officials, to become more critically conscious of the social, political, and economic factors that foster violence against women and form significant barriers to women's survival. Increased critical consciousness includes counseling psychologists' awareness of how their values, beliefs, and practices reinforce structures of injustice. For example, counseling psychologists must become more critically aware of how theories of psychotherapy fail to address the effect of women's environments on development and how many psychologists push women to leave abusive partners because of the view that this as the only valid movement toward empowerment (McWhirter, 1997; Vera \& Speight, 2003). To foster liberation, counseling psychologists also must work collaboratively with other community members to use collective skills and resources in addressing domestic violence at broader levels of the ecology, including community interventions, distribution of research information, and political involvement. As community members increase their critical consciousness of oppressive and unjust social structures, they will better understand their par- 
ticipation in and maintenance of such social structures, and can choose to work collaboratively for social change.

Recently, vocational psychologists reaffirmed their challenge to psychologists, other social scientists, and mental health professionals to consider vocational issues as primary, contextual factors in individuals' lives and to create interventions that liberate or give voice to the oppressed and that help eliminate structures of injustice (Bingham, 2002; Blustein, McWhirter, \& Perry, 2004; DeBell, 2002; Gore, Leuwerke, \& Krumboltz, 2002; Heppner \& Davidson, 2002; Krieshok \& Pelsma, 2002; O'Brien \& Brown, 2001). It is important to include liberation in our discussions of vocational research and social change because liberation involves a critical awareness and transformation of one's individual identity and social identity, which must occur together because the individual is not separate from the community, society, and culture in which she lives and works (Martín-Baró, 1994). Thus, vocational research for the liberation of battered women increases our critical consciousness (i.e., as researchers, counselors, women survivors, members of society) of the impacts of domestic violence on women's vocational and economic development, and provides us with transformative knowledge. Let us discuss a specific example to further illustrate the potential of vocational research to contribute to the liberation of battered women.

Previous research indicates that economic independence is paramount in restoring a battered woman's sense of power and control over her life situation (Sullivan, 1991). Battered women have identified financial resources as a major factor in their decisions to seek support, their ability to provide for family needs without their abusers' contributions, and their resolve to leave abusive situations (Sullivan, 1991). Sullivan and Bybee (1999) conducted an experimental investigation of the effectiveness of an advocacy program for battered women. They found that women who had advocates, people who helped them access community resources and negotiate social service and legal systems, experienced less violence over time, reported a higher quality of life and support, and experienced less difficulty accessing community resources than did women in the control condition. Thus, it is important that career-counseling assistance addresses women's immediate financial and employment needs as well as their longer term economic needs. Neglecting their economic and career potential often results in their struggling to financially support themselves and their families in the long term, thereby increasing the risk for returning to their abusive partners and a cycle of violence (Sullivan, Basta, Tan, \& Davidson, 1992). A short-term financial focus also fails to capitalize on the benefits of longer term collaboration between counselors and women's communities and on the possibility for transformation of community services for women survivors (Walsh \& Osipow, 1994). 
Given the critical role that career-development interventions may play in enhancing battered women's economic independence, vocational research that addresses social justice issues, informs policy, and empowers battered women in their career-related and personal-life decision making can make significant contributions to domestic-violence prevention efforts (Fassinger, 2001; Gianakos, 1999; Ibrahim \& Herr, 1987). Specifically, vocational research that identifies career assessment, counseling, and intervention strategies may be implemented with professionals working in a broad range of settings (social service agencies, state employment agencies, educational settings, religious organizations) to (a) improve women's access to resources (housing, counseling, postsecondary education, support network); (b) expand their career interests and goals, which may increase career satisfaction and economic stability; (c) support the realization of their educational and career potential; (d) advance their contributions to their communities; and (e) raise their levels of critical consciousness regarding the impact of domestic violence in their lives. Vocational research designed to reduce the risk of and to prevent domestic violence has the potential to provide battered women with the resources needed to take action to live free from violence- - that is, liberation.

\section{AN EMANCIPATORY COMMUNITARIAN APPROACH TO VOCATIONAL RESEARCH}

In 1997, Isaac Prilleltensky expressed concern about the lack of clear guidelines by which psychologists evaluate the ethical and moral implications of their work. He asserted that researchers who claim to be value neutral and objective during research processes risk engaging in oppressive power dynamics and reinforcing unjust social structures. From this perspective, he articulated the values, assumptions, and practices of an emancipatory communitarian approach to psychological practice, inclusive of conducting research. This approach to research (a) places equal importance and value on the common good and individualistic visions of the good life (communitarian) and (b) contends that to pursue the good life, individuals and communities must be free to define and pursue their goals (emancipation). Its primary aim is to liberate individuals and communities from oppression by engaging in research that is rooted in emancipatory communitarian values, assumptions, and practices (see Table 1).

Prilleltensky's values, assumptions, and practices, as described in Table 1, are not presented in an order that gives priority to any one of these over the others. An emancipatory communitarian approach supports a balance among 
TABLE 1: Values, Assumptions, and Practices ${ }^{\mathrm{a}}$ of an Emancipatory Communitarian Approach (Prilleltensky, 1997) to Psychological Research

\begin{tabular}{|c|c|c|}
\hline Values & Assumptions & Practices \\
\hline $\begin{array}{l}\text { Caring and compassion: } \\
\text { Researchers' and partici- } \\
\text { pants' manifestation of } \\
\text { care for others' well- } \\
\text { being as expressed in the } \\
\text { research agenda and the } \\
\text { process by which research } \\
\text { is carried out. }\end{array}$ & $\begin{array}{l}\text { Knowledge: Researchers } \\
\text { gain knowledge from par- } \\
\text { ticipants and distribute } \\
\text { knowledge to many dif- } \\
\text { ferent audiences (partici- } \\
\text { pants, stakeholders, policy } \\
\text { makers, scholars, practi- } \\
\text { tioners) to promote social } \\
\text { justice. }\end{array}$ & $\begin{array}{l}\text { Problem definition: The } \\
\text { assessment and conceptu- } \\
\text { alization of a psychologi- } \\
\text { cal or social problem that } \\
\text { relates to oppression of } \\
\text { people and communities. }\end{array}$ \\
\hline $\begin{array}{l}\text { Self-determination: Partici- } \\
\text { pants' ability to pursue } \\
\text { their chosen goals in } \\
\text { collaboration with their } \\
\text { community and the } \\
\text { researcher's ability to } \\
\text { empower participants } \\
\text { and communities. }\end{array}$ & $\begin{array}{l}\text { Good life: Researchers and } \\
\text { participants articulate } \\
\text { their visions of well- } \\
\text { being, which, in turn, } \\
\text { inform the research } \\
\text { process. }\end{array}$ & $\begin{array}{l}\text { Role of the client (partici- } \\
\text { pant): Participants collab- } \\
\text { orate with researchers to } \\
\text { define, understand, and } \\
\text { test a problem or inter- } \\
\text { vention. Participants are } \\
\text { actively involved in the } \\
\text { research process. }\end{array}$ \\
\hline $\begin{array}{l}\text { Human diversity: Research- } \\
\text { ers and participants pro- } \\
\text { mote knowledge, inclu- } \\
\text { sion, and respect of } \\
\text { diverse social identities. }\end{array}$ & $\begin{array}{l}\text { Good society: Researchers } \\
\text { and participants articulate } \\
\text { their visions of a good } \\
\text { society, which, in turn, } \\
\text { informs the research pro- } \\
\text { cess. Research helps build } \\
\text { a just society rather than } \\
\text { maintaining the status quo. }\end{array}$ & $\begin{array}{l}\text { Role of the helper: While } \\
\text { recognizing the value of } \\
\text { different roles for different } \\
\text { situations or needs, re- } \\
\text { searchers collaborate with } \\
\text { individuals and communi- } \\
\text { ties to promote social } \\
\text { change. }\end{array}$ \\
\hline $\begin{array}{l}\text { Collaboration and demo- } \\
\text { cratic participation: Peace- } \\
\text { ful and respectful process } \\
\text { by which participants (and } \\
\text { researchers) have input } \\
\text { into decisions affecting } \\
\text { their lives, including } \\
\text { research questions, de- } \\
\text { signs, and participation. }\end{array}$ & $\begin{array}{l}\text { Power in relationships: } \\
\text { Researchers consider how } \\
\text { relationships with partici- } \\
\text { pants influence outcomes, } \\
\text { and they attempt to } \\
\text { acknowledge and/or dis- } \\
\text { tribute that influence } \\
\text { fairly. }\end{array}$ & $\begin{array}{l}\text { Type of intervention: Re- } \\
\text { search is grounded in the } \\
\text { knowledge base of indi- } \\
\text { viduals and communities, } \\
\text { as well as scholars. Inter- } \\
\text { ventions (and the research } \\
\text { designs used to test inter- } \\
\text { ventions) are based on } \\
\text { that knowledge and on } \\
\text { the value of distributive } \\
\text { justice. }\end{array}$ \\
\hline $\begin{array}{l}\text { Distributive justice: Fair } \\
\text { allocation of resources } \\
\text { and power for individuals } \\
\text { and for communities. }\end{array}$ & $\begin{array}{l}\text { Professional ethics: Re- } \\
\text { search provides a service } \\
\text { and promotes distributive } \\
\text { justice. Research partici- } \\
\text { pants take part in ethical } \\
\text { decision making. }\end{array}$ & $\begin{array}{l}\text { Time of intervention: Focus } \\
\text { of intervention is on the } \\
\text { prevention/intervention } \\
\text { continuum, including } \\
\text { applied research in field } \\
\text { settings. }\end{array}$ \\
\hline
\end{tabular}

a. There is no direct and exclusive relationship among the values, assumptions, and practices presented in each row. 
all of these values as part of the research process and as desired outcomes (Prilleltensky, 1997). We use this approach to research because of its emphasis on the good of the individual and the community through elimination of structures of injustice. This individual and social/community focus facilitates the process of liberation-the transformation of one's individual and collective realities (Martín-Baró, 1994).

Prilleltensky (1997) states, "The practice of an emancipatory communitarian approach would examine the role of oppression and lack of responsibility toward people in positions of disadvantage" (p. 530). As vocational researchers, we are not facilitating women's emancipation and addressing structures of injustice if our research and practices assist women only with finding short-term employment and financial resources. This kind of research is not representative of emancipatory communitarian values of distributive justice and caring and compassion for all. That is, vocational research for the liberation of battered women must include examination of counseling strategies and interventions that advance women's vocational and economic attainments over time such that women are able to access more power and resources and contribute fully to our society. In the next section, we use the emancipatory communitarian approach to outline a vocational research agenda and to describe research practices that foster collaboration among researchers, women survivors, and communities, and that facilitate women's identification of their needs and community responsibilities.

\section{A VOCATIONAL RESEARCH AGENDA WITH BATTERED WOMEN}

\section{Vocational Theories and Assessment}

One of the most significant challenges for vocational researchers is to identify career theories that apply to the work experiences of battered women, which do not necessarily follow an uninterrupted, linear pursuit of a career. In particular, women from lower socioeconomic and less-educated backgrounds are not necessarily afforded the time or resources to pursue careers that may serve as means to realize their potential. Rather, many battered women work solely as a means for survival.

Researchers are beginning to address shortcomings in career theory as they pertain to vocational research with battered women. Blustein et al. (2004) distinguish between people's experiences of work and career and use the emancipatory communitarian approach to discuss the creation of new vocational development theories. They comment, 
Despite the promise that a psychological study of careers offers people, the reality is that most career development theories have been developed from the perspective of white middle class males and have served the interests of those who have the privilege of a self-determined career. (p. 3)

Blustein et al. (2004) suggest that new vocational theories need to be developed for the working poor and those who work to survive financially.

Also adding to career-development theory regarding women survivors of domestic violence, Chronister and McWhirter (2004b) provided quantitative data that support social-cognitive career theory (SCCT) (R. W. Lent, Brown, $\&$ Hackett, 1994) as a useful framework for conceptualizing the career experiences and needs of battered women. Chronister and McWhirter (2004a) experimentally tested the effectiveness of two group career interventions designed specifically for battered women and grounded in SCCT. One of the programs also incorporated features of critical consciousness. Results showed significant increases in career search self-efficacy and critical consciousness of domestic-violence scores for intervention participants at posttest relative to a control group. In addition, women who participated in the intervention that incorporated features of critical consciousness reported more progress toward their career goals at follow-up. To date, the study conducted by Chronister and McWhirter (2004b) is the only empirical examination of theory with battered women.

An emancipatory communitarian approach to the development of vocational theories and assessment measures or procedures must include researchers' advancement of the values of human diversity, collaboration with women survivors, and women's democratic participation in research processes. These values are congruent with the emancipatory communitarian assumptions and practices that recognize battered women as researchers' greatest source of knowledge and that use women's voices in defining their visions of a good life and good society. In keeping with these values and assumptions, vocational researchers may improve vocational theories and assessment measures for battered women by engaging in emancipatory communitarian research practices that include women in defining salient theoretical variables and constructs as well as research questions and hypotheses.

For research in the area of vocational theory development with battered women, we recommend research that uses qualitative and quantitative methodologies:

1. More qualitative research that explores how battered women's access to vocational opportunities and financial resources vary as a function of their cultural backgrounds (i.e., ethnicity, social class, sexual orientation, ability, etc.) and abuse experiences. Qualitative methodology allows researchers to capture the human diversity in battered women's experiences and could help researchers 
test vocational theories that may arise from a greater understanding of women's diverse experiences.

2. More qualitative research that identifies how domestic violence impacts different stages of women's vocational development (e.g., career adjustment, advancement, and satisfaction). Research suggests that experiences of domestic violence, especially for women on welfare, may not impact their ability to obtain employment (Tolman \& Rosen, 2001) but rather their ability to maintain long-term employment (American Psychological Association [APA], 1996; Browne et al., 1999). More research is needed to identify how domestic violence differentially impacts women's self-determination.

3. More qualitative investigations to contrast the personal and career experiences of battered women who are employed or attending school and those not employed or attending school—specifically, qualitative investigation that examines how work contexts (e.g., employers, coworkers, and work policies) strengthen or diminish a woman's ability to survive an abusive relationship. This type of research will help researchers better understand the effect of women's contexts on their ability to pursue goals and overcome barriers.

4. More quantitative investigations on how work, career satisfaction, and battered women's definitions of the good life influence their self-concept, efficacy, hopefulness, and outcome expectations—outcomes for which quantitative measures have been developed (Betz, Klein, \& Taylor, 1996; Chronister \& McWhirter, 2004a; Coopersmith, 1987; Snyder et al., 1991; Solberg, Good, \& Nord, 1994; Wettersten, in press).

5. More qualitative research that explores the influence of larger systems (e.g., contact with government and law enforcement agencies, public policies, and cultural expectations and norms) on battered women's vocational development. Researchers who consider contextual influences are less likely to engage in research practices that define the "problem" as lying solely with the battered woman and create interventions that focus only on the individual.

6. More quantitative research, including the use of advanced statistics (path analysis, structural equation modeling), to establish empirical support for new and extant vocational theories and to define the interrelationships among vocational constructs. Such a quantitative agenda is important for identifying complex interrelationships among career variables salient for battered women and could make use of both one-time survey and longitudinal methodologies.

Like career theories, there are few vocational-assessment instruments that measure constructs that are meaningful to battered women's experiences or that have been validated with this population. Thus, we stress the importance of qualitative research to further our development of assessment instruments and quantitative research that involves gathering reliability and validity evidence for measures used with battered women. Chronister and McWhirter (2004a) gathered reliability and validity evidence for vocational instruments measuring battered women's career-search self-efficacy, career outcome expectations, and perceived contextual barriers and supports. Data with a 
sample of 75 women residing in domestic-violence shelters yielded strong reliability and validity evidence for the career-search self-efficacy and outcome-expectations measures. Reliability and validity evidence for the career barriers and supports measures was moderate to weak. In another study, C. Brown et al. (2000) used vocational measures of perceived career barriers and career-related self-identity and control variables to examine predictors of battered women's career decision-making self-efficacy. Findings of this investigation revealed that higher perceptions of career barriers were related to an external expectancy, and self-esteem emerged as the most significant contributor to battered women's self-efficacy for career decision-making tasks. Moreover, these women regarded discrimination, inadequate preparation, and dissatisfaction with career as the greatest hindrances to their career pursuits. To date, these are the only career measures for which validity information has been collected with battered women. These endeavors represent only a starting place, however, with regard to vocational assessment with battered women.

An emancipatory communitarian approach to vocational assessment involves enhancing our knowledge of women's vocational development within larger contexts and addressing diversity issues in our assessment of women's vocational needs and goals. In addition, it includes testing the accuracy and inclusiveness of our assumptions about women's vocational experiences, visions of the good life, and aspirations for contributing to a good society.

To further vocational-assessment research with battered women, we recommend the following:

1. More qualitative research to inform construction of vocational measures that assess outcomes important to diverse groups of battered women (e.g., ethnic minority and immigrant women, women in same-sex partnerships, women with disabilities, etc.). For example, feminist theory and practice have increased our critical consciousness of domestic violence and, at the same time, advanced the idea that women must leave abusive partners. As a result, many of our vocational counseling interventions have focused on getting women financial resources to leave abusive situations rather than on accessing financial and mental health support for themselves, their partners, and their families (e.g., children). For vocational assessments to represent our value for human diversity and accurately capture themes, patterns, and changes in women's vocational development, we must include outcomes that are important to diverse groups of women.

2. Construction of vocational measures that include the specific vocational experiences of battered women. For example, perceived-career-barriers measures might include items such as, "Couldn't go to work because of physical injuries from partner" or "Lost job because of time spent in legal proceedings" (Riger, Ahrens, \& Blickenstaff, 2000). 
3. Qualitative and quantitative research examining the utility of different forms of vocational assessment (e.g., interview, self-report, behavioral, multiplerater assessments, and computers) and different information gathered from using different forms of assessment. For example, assessment with women must account for how gender role socialization, experiences of violence, and other forms of oppression may result in women's significant underreporting of their skills, abilities, and achievements (Gilbert \& Brownson, 1998; Walsh, 1997; Walsh \& Osipow, 1994; Whiston \& Bouwkamp, 2003).

4. More research evaluating the effectiveness of computer- and Internet-based assessments and career information that may allow women to gain experience with computers, participate in research activities, and access career support if they cannot leave their homes (e.g., immobility, injury, constraints from abusive partner). Although poorer women may not have access to their own computers, Chronister and McWhirter (2004b) used computer assessments and intervention software available for free on computers in public libraries, community colleges, and employment and social service agencies to significantly increase battered women's career-search self-efficacy. This study is an excellent example of an emancipatory communitarian approach to research that includes community collaboration to increase women's access to resources.

5. More reliability and validity data gathered for new and extant vocational measures.

\section{Career Interventions}

An emancipatory communitarian approach to career-intervention research involves increasing women's self-determination, democratic participation, and pursuit of the good life and good society as they define it. Vocational researchers risk reinforcing women survivors' feelings of helplessness and oppression by creating interventions without personal experience, knowledge, and consultation with women and their communities; by collecting data without providing a service to women participants; and by entering the research process as "expert," thereby sharing little information and power with women participants. Instead, vocational researchers may forward emancipatory communitarian values by engaging in practices that include women in problem definition and construction of research hypotheses and outcomes and that examine the effectiveness of different types of interventions across time.

Vocational researchers have outlined specific career-counseling guidelines with battered women, which include providing women with opportunities to develop new skills, gain career-related knowledge, and address the impact of domestic violence on social-cognitive-related variables (Bowen, 1982; C. Brown, 2001; Chronister \& McWhirter, 2003, 2004a, 2004b; Gianakos, 1999; Ibrahim \& Herr, 1987). Many of these guidelines have 
not been tested empirically. An emancipatory communitarian approach to career-intervention research involves researchers, battered women participants, and members of battered women's communities working together to answer the question, "What intervention strategies are effective with which battered women, in what settings, and at what times?" (S. D. Brown \& Krane, 2000).

In one of the only empirical career-intervention studies conducted with battered women, Chronister and McWhirter (2004b) created two 5-week, group, career-intervention programs designed to increase battered women's career-search self-efficacy, outcome expectations, and critical consciousness of the impact of domestic violence on their lives. As described previously, results indicated that career-program participation resulted in significant increases in battered women's career-search self-efficacy and goal achievement. Replication of this research and examination of the effectiveness of other career interventions and career-counseling strategies with battered women are necessary.

In the area of career-intervention research with battered women, we recommend the following:

1. Quantitative and qualitative investigations on how to create and implement effective career interventions for battered women across settings (e.g., shelter, transitional housing, employment, school, and community agency). Vocational research may provide information about women's vocational needs and how employers, educators, and social service providers can meet those needs by using the distinct resources of various settings.

2. Quantitative and qualitative investigations that help answer, "How might effective career practice vary as women's experiences of domestic violence change over time?" For example, the needs of a battered woman who is currently living in transitional housing and has not experienced domestic violence for 2 years may be very different from when she first entered a domesticviolence shelter.

3. Quantitative and qualitative investigations on how the effectiveness of career interventions varies with the timing of intervention implementation and counseling strategies used. That is, how can we vary the timing of careerintervention implementation (e.g., primary prevention efforts, such as psychoeducational career interventions in high schools; vs. secondary prevention efforts, such as career interventions in state employment agencies; vs. tertiary prevention efforts, such as interventions in postsecondary institutions for battered women in schools) to effectively address different needs along a domestic-violence prevention/intervention continuum.

4. More research examining how implementation of routine career services influence agencies' service provision (including primary, secondary, and tertiary prevention/intervention services), clientele, and funding priorities. That 
is, how does social service provision change as a result of an agency's increased attention to battered women's career development?

5. More research that examines the impact of public policies on women's vocational development and the development and implementation of effective interventions. For example, the U.S. Office of Justice Programs, the Family Violence Prevention Fund, and the Corporation for Financial Resources for Women and Children have introduced grant funding for research and community efforts that address "career counseling and skills training services for women." In addition, welfare reform has focused on moving women immediately into jobs, often at the expense of furthering women's educational and vocational training (Duncan \& Chase-Lansdale, 2001). Public policies have a direct impact on the types of jobs, training, and education that women are able to pursue. Vocational research has the potential to inform public-policy development and increase the effectiveness of how governments expand women's vocational opportunities, foster their self-determination, improve their access to resources, and support their pursuit of the good life.

\section{VOCATIONAL RESEARCH PRACTICES AND THE EMANCIPATORY COMMUNITARIAN APPROACH}

In addition to the content of a vocational research agenda, we also recommend an emancipatory communitarian approach to shape the practices of vocational researchers who work with battered women. Specifically, we suggest that the emancipatory communitarian themes of care and compassion, self-determination, human diversity, collaboration and democratic participation, and distributive justice be brought to bear on how vocational research with battered women is conducted and how it is distributed. These researchprocess issues include building collaborative relationships with community stakeholders and participants; making research accessible to the diverse individuals who experience domestic violence; giving extra consideration to informed consent, confidentiality, mandatory reporting, and dual relationships; providing resources to participants; and distributing research findings.

\section{Building Collaborative Partnerships}

An emancipatory communitarian approach to research includes building collaborative research partnerships to increase democratic participation by women and community members and to facilitate distribution of power (Chronister \& McWhirter, 2003; Browne et al., 1999; Fisher et al., 2002; Prilleltensky \& Nelson, 2002). Collaboration among community partners and researchers has become increasingly important because of the multiple forms of expertise offered by both groups. In addition, many community 
members want authentic participation in research and regard research that benefits only the researcher and gives nothing back to the community to be exploitative (Riger, 1999). These community partners and stakeholders are requesting a researcher-community exchange relationship whereby their knowledge and expertise as well as that of the researcher can be combined to liberate battered women, improve services, and inform policy.

Collaborative research partnerships may range from joint development of research goals, recruitment process/procedures, and even interpretation of the findings to researchers' engaging in regular or occasional consultation with community representatives about how to best address the needs of women survivors. A noted hallmark of collaborative research partnerships is the interest to share control of all aspects of the research process and to involve all participants, including advocates, service providers, community representatives, and women survivors. Collaborative research partners, therefore, may include women survivors and/or staff from domestic-violence agencies, shelters, hospitals, dental offices, welfare programs, employment agencies, urgent-care clinics, cultural centers, and religious/faith organizations. We list medical professionals as collaborative partners, in particular, to include the experiences of battered women with disabilities and women who receive medical attention following a domestic-violence incident.

Collaborative community partnerships allow vocational researchers to recruit a more representative sample of battered women because researchers are working with the communities in which women live and work. Collaborative partnerships may also provide researchers with the consultation services of knowledgeable staff who can help with interviewer training, wording of assessment questions, and analysis and interpretation of data (Ellsberg $\&$ Heise, 2002) and who can provide other resources, such as building space, research-team members, and participant referrals.

Collaborative research partnerships also enhance vocational researchers' credibility, which is important for working with all battered women and especially with survivors who are ethnic and racial minorities, immigrants, or involved in same-sex partnerships. Women of color may be concerned about participating in research activities because of fears of stereotyping and of racial loyalties (i.e., being loyal to the value for privacy held by her racial/ ethnic group and, as a result, not seeking help from those outside of her family). Immigrant women may fear that research participation will result in difficulties with immigration authorities or feel reluctant to participate because of geographic isolation or language and cultural barriers (Kanuha, 1994; Masaki \& Wong, 1997; Root, 1996; Yoshihama, 2000). Women in same-sex partnerships may fear researchers' homophobia or fear being "outed" (Bailey, 1996; Mahoney, Williams, \& West, 2001; Ristock, 2001). Researchers who are credible and trustworthy are better able to recruit battered- 
women participants from all cultural backgrounds and to offer research information broadly to advance career-counseling services for women in numerous settings.

\section{Participant Recruitment and Retention}

Research information, recruitment materials, and confidentiality. Conducting vocational research with survivors of domestic violence necessitates special considerations in the recruitment and retention of participants. The primary goal of these considerations is the safety and autonomy of the battered woman. Confidentiality is a paramount concern associated with investigating battered women's vocational needs (Campbell \& Dienemann, 2001). If confidentiality is breached, the risks to battered women include, but are not limited to, retribution from an abusive partner, stereotyping, and legal complications (e.g., loss of child custody; Kanuha, 1994).

With regard to distribution of recruitment materials (e.g., flyers), we recommend that researchers distribute information directly to community stakeholders and recruit by word of mouth. Community stakeholders may include domestic-violence services-agency staff, specific ethnic-group communityagency staff, religious officials, employment-agency personnel, and school officials (e.g., K-12 school officials for women who have children and postsecondary and vocational-training institutions). Women's safety is better protected if researchers work with community partners who understand potential threats to women's safety and confidentiality. In addition, researchers may create recruitment materials that ask for women participants who have experienced abuse in general as opposed to women who have experienced domestic violence in particular. Recruitment materials that advertise more generally, especially in smaller urban and rural communities, may prevent abusive partners from learning the research purpose. In circumstances where this more general recruitment-advertisement approach is applied to minimize potential repercussions by the abusive partner, it would be necessary to explain to those who are considering participation but whose abuse fails to meet the inclusion criteria of domestic violence that the study purpose is more directly related to domestic-violence abuse and that the more general advertisement was used so as to not compromise their safety. These women would therefore be excused from participation and thanked for their interest to participate. Such a general recruitment approach may not be necessary in larger urban settings where anonymity may be possible.

We encourage researchers to make the consent process ongoing, which means presenting participants with continued opportunities to decline participation. Given the power dynamics of domestically violent relationships, it is 
likely that many women have not been allowed to make autonomous decisions. Ongoing consent facilitates battered women's self-determination and democratic participation in research activities. Ongoing consent can be implemented for vocational research activities that occur only one time. Researchers may remind participants that they do not have to complete all of the vocational measures if they become seriously distressed during the time it takes to complete the battery, or researchers may check in once with the battered woman to see if she feels safe and comfortable with her participation in, for example, a brief 2-hour career intervention.

To protect participants' confidentiality, researchers must educate themselves, research-team members, and participants about mandated requirements to breach confidentiality in cases of known or suspected child abuse (Kalichman, 1999) and imminent danger. Campbell and Dienemann (2001) suggest providing verbal and written information about mandatory-reporting laws as part of obtaining informed consent, continually reminding women about the researcher's requirement of mandated reporting, and, if at all possible, filing a report in conjunction with the research participant. To reduce the risk of a breach of confidentiality, researchers also may consider obtaining a Certificate of Confidentiality (COC) and/or working with an institutional review board to waive signed informed consent. A COC can be obtained from the National Institute of Health, the Office of Assistant Secretary of Health, or the Public Health Service, and it allows for protection from subpoenas and other legally ordered breaches of confidentiality (except those related to mandatory reporting).

Dual relationships increase the risk of confidentiality breaches. Although multiple relationships are inevitable, we do not recommend that a researcher who knows a woman from another context (other than the research setting) engage in multiple roles with her without consent. We found it helpful to provide participants with a picture of the research team or a list of first names and last initials of researchers and research-team members. These provisions allow women to make an informed choice as to whether they want to work with someone they know.

In keeping with an emancipatory communitarian approach, we support participant recruitment and retention research practices that communicate care and attention to women's emotional and physical health and that foster women's democratic participation and self-determination. We assume that liberating battered women includes sharing our power as researchers, increasing women's knowledge of participation risks, and facilitating their ability to make decisions that best serve their interests.

Resources for participants. Participant recruitment and retention extends beyond referrals and protecting women's confidentiality. In accordance with 
the emancipatory communitarian values of compassion, self-determination, and distributive justice, we believe that it is important for researchers to be aware of the career and personal resources that women need (Betz \& Corning, 1993). Consequently, we recommend that researchers facilitate women's connection to resources by providing a list of social service, educational, and vocational resources (e.g., agencies, books, and Internet sites). Researchers might speak with women to identify the resources best able to meet their needs beyond participation in research activities. With careful consideration of confidentiality, we also encourage researchers to connect women with community members who may serve as role models and mentors to strengthen women's support network and to facilitate continued career-development progress.

Other resources might include research compensation in the form of money, gift certificates, bus passes, child care, and career-related resources such as charity vouchers to purchase professional clothing (e.g., suits, uniforms), computer software, or educational materials. Vocational researchers must consider welfare laws. Paying participants more money is not necessarily better. Some state welfare laws require women to report money earned from participating in research activities against their income, if over a certain amount. We also recommend that researchers pay women with cash or money orders and not checks because abusive partners may control all finances (Gragg, 2001).

Research activities should be held in a secure area that is easily accessible, particularly for women with physical disabilities. In a qualitative study, Wettersten et al. (in press) identified transportation as one example of a barrier to self-sufficiency among rural women in shelter from domestic violence. In addition, E. B. Lent (1999) indicated that barriers such as road construction, lack of clear directions, or no parking space deterred some battered-women participants from attending research activities.

Disseminating research results. Part of the emancipatory communitarian approach to research is disseminating research knowledge in a way that will transform social structures (Prilleltensky \& Nelson, 2002). We believe that vocational research with battered women is important to the extent that research findings raise public consciousness (concientización), inform the development of career-counseling interventions, and influence social policy (Ellsberg \& Heise, 2002; Fassinger, 2001; Prilleltensky \& Nelson, 2002). Many vocational researchers do not have the time or funding, however, to disseminate research findings broadly. Thus, we recommend that vocational researchers work collaboratively with community stakeholders and research-team members to write research results and disseminate information to be useful to researchers and practitioners. Riger (1999) noted that a 
hallmark of collaborative research is the involvement of all research partners, from conceptualization through data collection and dissemination of findings.

We encourage researchers and community stakeholders to publish research results in professional journals, magazines, organizational newsletters, and bulletins that reach a broad range of professionals (i.e., legislators, social scientists, and educators). Researchers and community stakeholders also may publish research results on Web sites and send research announcements to professional associations and committees. Prilleltensky and Nelson (2002) identified the use of video productions, short progress reports, and consultation meetings and workshops for disseminating research results.

Disseminating vocational research broadly is a primary way to advance the development of preventive-intervention vocational services for battered women and to promote distributive justice. Researchers may target advertising and/or may implement preventive-intervention research efforts in health care settings including, hospitals, dentists' offices, and urgent-care clinics. Many battered women access health care following a physical-abuse experience or frequent health care settings regularly for services for their children. In addition, researchers may target their research efforts in work settings, state employment offices, and legal-aid services. Vocational researchers might use their research findings to write training grants to fund the implementation of career counseling and assessment practica in domestic-violence shelters and advocacy-center settings. Data from vocational research with battered women can also be used to encourage the development of public policy that funds programs and services designed to advance the vocational and economic development of battered women. To effect social change, vocational researchers must extend themselves beyond institutional boundaries and work actively and creatively to communicate the value of their research to the communities in which battered women live and work (Prilleltensky \& Nelson, 2002; Vera \& Speight, 2003).

\section{CONCLUSION}

Our goal in writing this article was to describe a vocational research agenda with battered women and present an emancipatory communitarian approach to research that advances women's career and economic attainments, promotes distributive justice, and creates social change. We believe that vocational research that (a) is conducted with care and compassion and that (b) includes the women in research processes can help facilitate the liberation of battered women. 


\section{REFERENCES}

American Psychological Association. (1996). Violence and the family (Report of the American Psychological Association, Presidential Task Force on Violence and the Family). Washington, DC: American Psychological Association.

Bailey, G. R., Jr. (1996). Treatment of domestic violence in gay and lesbian relationships. Journal of Psychological Practice, 2, 1-8.

Betz, N. E., \& Corning, A. F. (1993). The inseparability of "career" and "personal" counseling. Career Development Quarterly, 42(2), 137-142.

Betz, N. E., Klein, K. E., \& Taylor, K. M. (1996). Evaluation of a short form of the Career Decision-Making Self-Efficacy Scale. Journal of Career Assessment, 4, 47-57.

Bingham, R. P. (2002). The issue may be the integration of personal and career issues. The Counseling Psychologist, 30(6), 885-890.

Blustein, D. L., McWhirter, E. H., \& Perry, J. C. (2004). Toward an emancipatory communitarian approach to vocational development theory. Manuscript in preparation.

Bowen, N. H. (1982). Guidelines for career counseling with abused women. Vocational Guidance Quarterly, 31(2), 123-127.

Brown, C. (2001, August). Career counseling training in domestic violence shelters. Paper presented at the annual meeting of the American Psychological Association, San Francisco.

Brown, C., Reedy, D., Fountain, J., Johnson, A., \& Dichiser, T. (2000). Battered women's career decision-making self-efficacy: Further insights and contributing factors. Journal of Career Assessment, 8(3), 251-265.

Brown, S. D., \& Krane, N. E. (2000). Four (or five) sessions and a cloud of dust: Old assumptions and new observations about career counseling. In S. D. Brown \& R. W. Lent (Eds.), Handbook of Counseling Psychology (3rd ed.). New York: Wiley.

Browne, A., Salomon, A., \& Bassuk, S. S. (1999). The impact of recent partner violence on poor women's capacity to maintain work. Violence Against Women, 5, 393-426.

Campbell, J. C., \& Dienemann, J. D. (2001). Ethical issues in research on violence against women. In C. M. Renzetti, J. L. Edleson, \& R. K. Bergen (Eds.), Sourcebook on violence against women (pp. 57-72). Thousand Oaks, CA: Sage.

Chronister, K. M., \& McWhirter, E. H. (2003). Women, domestic violence, and career counseling: An application of social cognitive career theory. Journal of Counseling and Development, 81(4), 418-424.

Chronister, K. M., \& McWhirter, E. H. (2004a). Ethnic differences in battered women's perceptions of career barriers and supports: A pilot study. Journal of Career Assessment, 12(2), 169-187.

Chronister, K. M., \& McWhirter, E. H. (2004b). An experimental examination of two career counseling programs for battered women. Manuscript submitted for publication.

Comas-Díaz, L. (1994). An integrative approach. In L. G. Comas-Díaz \& B. Greene (Eds.), Women of color: Integrating ethnic and gender identities in psychotherapy (pp. 287-318). New York: Guilford.

Coopersmith, S. (1987). Self-esteem inventories. Palo Alto, CA: Consulting Psychologist Press.

Corporate Alliance to End Partner Violence (CAEPV). (2002). Facts and statistics. Retrieved April 14, 2002, from http://www.caepv.org

DeBell, C. (2002). Practice for a paradigm shift: A complete model for an integrative course. The Counseling Psychologist, 30(6), 858-877.

Duncan, G. J., \& Chase-Lansdale, C. (2001). For better and for worse: Welfare reform and the well-being of children and families. New York: Russell Sage Foundation.

Ellsberg, M., \& Heise, L. (2002, May). Bearing witness: Ethics in domestic violence research. The Lancet, 359, 1599-1604. 
Fassinger, R. (2001, March). Social action at the national level: On dismantling the master's house. Paper presented at the meeting of the Society for Vocational Psychology, Houston, TX.

Fisher, C. B., Hoagwood, K., Boyce, C., Duster, T., Frank, D. A., Grisso, T., et al. (2002). Research ethics for mental health science involving ethnic minority children and youths. The American Psychologist, 57(12), 1024-1040.

Flitcraft, A. H., Hadley, S. M., Hendricks-Matthews, M. K., McLeer, S. V., \& Warshaw, C. (1992). Diagnostic and treatment guidelines on domestic violence. Chicago: American Medical Association.

Freire, P. (1970). Pedagogy of the oppressed. New York: Continuum.

Gianakos, I. (1999). Career counseling with battered women. Journal of Mental Health Counseling, 21(1), 1-14.

Gilbert, L. A., \& Brownson, C. (1998). Current perspectives on women's multiple roles. Journal of Career Assessment, 6(4), 433-448.

Gore, P. A., Leuwerke, W. C., \& Krumboltz, J. D. (2002). Technologically enriched and boundaryless lives: Time for a paradigm upgrade. The Counseling Psychologist, 30(6), 847857.

Gragg, K. M. (2001). Graduate research with women survivors of domestic violence (Report No. CG-031-311). East Lansing, MI: National Center for Research on Teacher Learning. (ERIC Document Reproduction No. ED 031 311)

Heppner, M. J., \& Davidson, M. M. (2002). Be careful what we wish for: The integration of career psychology. The Counseling Psychologist, 30(6), 878-884.

Ibrahim, F. A., \& Herr, E. L. (1987). Battered women: A developmental life-career counseling perspective. Journal of Counseling and Development, 65(5), 244-248.

Kalichman, S. C. (1999). Mandated reporting of suspected child abuse: Ethics, law and policy. Washington, DC: American Psychological Association.

Kanuha, V. (1994). Women of color in battering relationships. In L. G. Comas-Diaz \& B. Greene (Eds.), Women of color: Integrating ethnic and gender identities in psychotherapy (pp. 428454). New York: Guilford.

Krieshok, T. S., \& Pelsma, D. M. (2002). The soul of work: Using case studies in the teaching of vocational psychology. The Counseling Psychologist, 30(6), 833-846.

Lent, E. B. (1999). The challenge of lower socioeconomic status in job and career service delivery. Paper presented at the meeting of the Society for Vocational Psychology, Milwaukee, WI.

Lent, R. W., Brown, S. D., \& Hackett, G. (1994). Monograph: Toward a unifying social cognitive theory of career and academic interest, choice, and performance. Journal of Vocational Behavior, 45, 79-122.

Mahoney, P., Williams, L. M., \& West, C. M. (2001). Violence against women by intimate relationship partners. In C. M. Renzetti, J. L. Edleson, \& R. K. Bergren (Eds.), Sourcebook on violence against women (pp. 143-179). Thousand Oaks, CA: Sage.

Martín-Baró, I. (1994). Writings for a liberation psychology. Cambridge, MA: Harvard University Press.

Masaki, B., \& Wong, L. (1997). Domestic violence in the Asian community. In E. Lee (Ed.), Working with Asian Americans (pp. 439-451). New York: Guilford.

McWhirter, E. H. (1997). Empowerment, social activism, and counseling. Counseling and Human Development, 28(8), 1-14.

O’Brien, K. M., \& Brown, C. (2001, August). Counseling psychologists as agents of social change: Domestic violence interventions. In J. Swanson (Chair), Career counseling trainingempirical models, social justice settings, diverse populations. Symposium conducted at the meeting of the American Psychological Association, San Francisco. 
Plichta, S. B. (1996). Violence and abuse: Implications for women's health. In M. M. Falik (Ed.), Women's health: The Commonwealth Fund Survey (pp. 237-270). Baltimore: Johns Hopkins University Press.

Prilleltensky, I. (1997). Values, assumptions, and practices: Assessing the moral implications of psychological discourse and action. The American Psychologist, 52, 517-535.

Prilleltensky, I., \& Nelson, G. (2002). Doing psychology critically: Making a difference in diverse settings. New York: Palgrave Macmillan.

Retzlaff, C. (1999). A national study examining women's experience of violence in America. Retrieved January 5, 2001, from http://www.thebody.com/iapac/violence-women.html

Riger, S. (1999). Working together: Challenges in collaborative research on violence against women. Violence Against Women, 5, 1099-1117.

Riger, S., Ahrens, C., \& Blickenstaff, A. M. (2000). Measuring interference with employment and education reported by women with abusive partners: Preliminary data. Violence and Victims, 15, 161-172.

Ristock, J. L. (2001). Decentering heterosexuality: Responses of feminist counselors to abuse in lesbian relationships. Women and Therapy, 23, 59-72.

Romano, J. L., \& Hage, S. M. (2000). Prevention and counseling psychology: Revitalizing commitments for the 21st century. The Counseling Psychologist, 28, 733-763.

Root, M. P. (1996). Women of color and traumatic stress in "domestic captivity": Gender and race as disempowering statuses. In A. J. Marsella \& M. J. Friedman (Eds.), Ethnocultural aspects of posttraumatic stress disorder: Issues, research, and clinical applications (pp. 363387). Washington, DC: American Psychological Association.

Snyder, C. R., Harris, C., Anderson, J. R., Holleran, S. A., Irving, L. M., Sigmon, S. T., et al. (1991). The will and the ways: Development and validation of an individual-differences measure of hope. Journal of Personality and Social Psychology, 60, 570-585.

Solberg, V. S., Good, G. E., \& Nord, D. (1994). Career search efficacy: Ripe for applications and intervention programming. Journal of Career Development, 21, 63-72.

Sullivan, C. M. (1991). Battered women as active helpseekers. Violence Update, 1, 1, 8, 10.

Sullivan, C. M., Basta, J., Tan, C., \& Davidson, W. S. (1992). After the crisis: A needs assessment of women leaving a domestic violence shelter. Violence and Victims, 7(3), 267-275.

Sullivan, C. M., \& Bybee, D. I. (1999). Reducing violence using community-based advocacy for women with abusive partners. Journal of Consulting and Clinical Psychology, 67(1), 43-53.

Tjaden, P., \& Thoennes, N. (2000). Prevalence and consequences of male-to-female and femaleto-male violence as measured by the National Violence Against Women Survey. Violence Against Women, 6, 142-161.

Tolman, R. M., \& Rosen, D. (2001). Domestic violence in the lives of women receiving welfare: Mental health, substance dependence, and economic well-being. Violence Against Women, $7(2), 141-158$

U.S. Department of Justice. (1998). Violence by intimates: Analysis of data on crimes by current or former spouses, boyfriends, and girlfriends (BJS report, NCJ 167237). Washington, DC: Author.

U.S. Department of Justice, Bureau of Justice Statistics. (2000). Intimate partner violence. Retrieved March 12, 2004, from http://www.ojp.usdoj.gov/bjs/abstract/ipv.htm

U.S. Department of Justice, Bureau of Justice Statistics. (2001, October). Intimate partner violence and age of victim, 1993-99. Washington, DC: Author.

U.S. Department of Labor, Women's Bureau. (1996). Domestic violence: A workplace issue. Retrieved April 15, 2002, from http://www.dol.gov/dol/wb/public/wb_pubs/domestic.htm

Vera, E. M., \& Speight, S. L. (2003). Multicultural competence, social justice, and counseling psychology: Expanding our roles. The Counseling Psychologist, 31(3). 253-272. 
Walsh, W. B. (Ed.). (1997). Career assessment for women: Theory into practice [Special Issue]. Journal of Career Assessment, 5(4).

Walsh, W. B., \& Osipow, S. H. (Eds.). (1994). Career counseling for women. Mahwah, NJ: Lawrence Erlbaum.

Wettersten, K. B., Rudolph, S., Faul, K., Gallagher, K., Transgrud, H., Adams, K., et al. (in press). Freedom through self-sufficiency: A qualitative examination of the impact of domestic violence on the working lives of women in shelter. Journal of Counseling Psychology.

Whiston, S. C., \& Bouwkamp, J. C. (2003). Ethical implications of career assessment with women. Journal of Career Assessment, 11(1), 59-75.

Yoshihama, M. (2000). Reinterpreting strength and safety in a socio-cultural context: Dynamics of domestic violence and experiences of women of Japanese descent. Children and Youth Services Review, 22, 207-229. 